Case Report

\title{
Effects of Strong Government in Attaining Outstanding Performance on Construction Projects: Stakeholder's Opinions in Tanzania
}

\author{
Ramadhani Said Tekka', Saidi Mustapha Msangi \\ ${ }^{1}$ Department of Construction Management and Technology, College of Architecture and Construction Technology, Mbeya University of \\ Science and Technology, Mbeya, Tanzania \\ ${ }^{2}$ Department of Business Management, College of Humanities and Business Studies, Mbeya University of Science and Technology, Mbeya, \\ Tanzania
}

Email address:

ramsotekka@yahoo.co.uk (R. S. Tekka), smmsangi@gmail.com (S. M. Msangi)

\section{To cite this article:}

Ramadhani Said Tekka, Saidi Mustapha Msangi. Effects of Strong Government in Attaining Outstanding Performance on Construction Projects: Stakeholder's Opinions in Tanzania. Industrial Engineering. Vol. 4, No. 2, 2020, pp. 55-60. doi: 10.11648/j.ie.20200402.15

Received: December 24, 2019; Accepted: February 10, 2020; Published: September 10, 2020

\begin{abstract}
Attaining an outstanding performance in a construction project has for decades being a problem in Tanzania. Contractors have too many projects failed to conquer the project's value for money as a result of time extension, increase in cost with unsatisfactory quality. This study aims to identify the Tanzanian opinion on the effects of strong government in attaining outstanding performance on construction projects. The questionnaire and an-in-depth interview survey method were opted to collect the data from one hundred fifty-four (154) respondents obtained through purposely sampling technique. Microsoft Excel was used to analyze the quantitative descriptive data. The finding of the study has identified twelve (12) effects of a stable government on performance in construction industry in Tanzania: attainment value for money, fight against malpractices (corruption), timely project completion, timely project completion, society satisfaction with projects, society satisfaction with projects, community participation/local fundi, reduced of construction cost, abide to construction specification, increased quality social services, suspending of ghost engineer, de-register incompetent contractors, reasonable operational cost, timely payment grouped into four variables namely: an increased construction quality, fighting against malpractices, society satisfaction, and timely payment. However, the study has eventually proposed the measure to be considered for local firms to attain a sustainable, outstanding performance and growth.
\end{abstract}

Keywords: Tanzania, Construction Industry, Outstanding Performance, Construction Project, Value for Money

\section{Introduction}

The construction industry $(\mathrm{CI})$ plays an essential role and acts as a back born and a contributor to the overall economic growth of the nation [1]. Its contribution is attained through different constructed structures, including roads and bridges, railways, airports, telecommunication networks, and buildings [2] that accelerate development, improve performance, quality life as an achievement of the society's goals.

The contribution originates from the inter-linkages between the construction industry with another sector of the economy [3-5].
Because of its linkages, any changes in CI automatically affect other sectors of the economy. CI is one of the primary industries that contributes to about $10 \%$ of the Gross National Product (GNP) and Gross Domestic Product (GDP) in industrialize and developed countries [6] and about 5.5\%-7\% GDP to low and middle-income economy developing countries [7]. Tanzania in particular, as of 2014 the CI contribute to about $14 \%$ of the total GDP of $7.1 \%$.

Despite its fundamental significant importance, the CI in Tanzania is faced with multiple constraints [8] including lack of resources (finance, skilled human resources, local quality materials), incapacitated institute, miserable experience, knowledge and low skills, inadequate technology, lack of 
strategic planning and management skills, lack of core competence as well as historical poor performance $[9,10]$. As a result, the construction sector has prevailed in attaining poor image and fallen short of expected performance measured in terms of contract time overrun, budget, quality, safety, and environment $[11,12]$. In the same vein, [13] cemented that, most executed projects suffer from cost and time overruns, with an unsatisfactory quality and safety.

Different measures have been taken to improve the performance in terms of time, quality, cost, business performance and stakeholders satisfaction [14] These includes formation of agencies including Construction Registration Board (CRB), Engineer Registration Board (ERB), Architects and Quantity Surveyors Registration Board (AQRB), National Construction Council (NCC), Formation of Tanzania Roads Agency (TANROADS) and recently Tanzania Rural and Urban Roads (TARURA), Establishment of Construction Industry Policy (CIP, 2003), establishment of Contractors' Assistant Fund (CAF) in 2002 aimed to assist the junior contractors to access offer bonds and Bank assurances as guarantee for advance project payments.

Establishment of Tanzania Civil Engineering Contractors Association (TACECA) institution in 1996 intended to provides a common forum for local contractors to share experiences, leverage resources, and engage in effective advocacy with the Government, etc. Despite the efforts mentioned above, the performance improvements in the CI are still not guaranteed [15]. However, since the commencement of the current Tanzania government (2015 to-date) under the slogan of "Hapa Kazi," improved performance of Tanzania CI in terms of project cost-effectiveness, reduced malpractices, reasonable completion time, client and stakeholder's satisfaction to quality attained have been noted [16]. Thus, this has necessitated the researcher to undertake the study in assessing the effects of stable political government in achieving outstanding performance and construction projects value for money in Tanzania.

\section{Literature Review}

\section{a. Performance}

As noted by [17], performance is a hard concept to define and measure. While different interchangeable terms such as efficiency, effectiveness, improvement, growth, and success have been used by researchers and stakeholders to describe the term performance [18], a short service delivery time, working within allocated budget while attaining quality, safety, and client satisfaction [19] have been used as the Key Performance
Indicators (KPI) for performance measurement. However, despite the above mentioned KPI, the extension of the satisfaction has been extended to not only clients but also other stakeholders.

In Tanzania, the performance in many public projects as significant investments accounting to more than $90 \%$ of all development projects [20] has always been faced with inadequate performance. In a study by [21] to access the attainment of construction value for money in the Local Government Projects, it was noted that (71\%) representing (56) audited councils failed to manage the contracts properly, this led to inadequate performance to the projects. During the evaluation of TANROAD's reports, the assessment portrayed that, out of 96 road projects executed between (2005-2013), only $32 \%$ of the total projects were at least completed within the original completion period and budget [22]. However, the rest 68 indicated the vast discrepancies in terms of time and cost. Generally, it has been recognized that the overall problems in the executed project in Tanzania CI originate from the inadequate performance $[23,24]$.

b. Construction Projects

Ever since the commencement of the $5^{\text {th }}$ Tanzania government (in 2015) under His Excellence Dr. John Pombe Joseph Magufuli (Figure 1) famously nicknamed "Bulldozer" under his slogan of "Hapa Kazi Tu" which roughly translates as "strictly have business" or "actions only," has witnessed an improved performance to Tanzania Construction Industry. Various strategic construction projects have been implemented within the contract schedule, cost, and quality [16].

A study by [25] noted that, since 2016, Tanzania government has been providing funds for renovation, remodeling and expansion of building infrastructures for more than 33 secondary schools including Iyunga, Mpwapwa, Kibaha, Jangwani, Azania, and Nangwa, Ifunda, Bukoba, Iyunga, etc; and many teachers' colleges including Musoma, Nachingwea, Kasulu, Tukuyu, Korogwe, Morogoro, Mpwapwa, Songea, Marangu, Tabora, Butimba and Kleruu.

Other projects involve construction and renovation of Folk Development Colleges such as Ilula, Nzovwe, Katumba, Chala, Msaginya, Sikonge, Kihinga, Kibondo, Bariadi, Kasulu etc. Besides, funds have also been set for different road Construction such as Kasinde-Mpanda, Komanga-Kasinde, Widening of Morogoro road, Mbinga-Mbamba Bay, Selander Bridge, Ubungo and Tazara Flyover, Construction and expansion of airports, construction of government buildings, etc [26]. Most projects have been completed on time, within the budget, and have attained value for money [16].

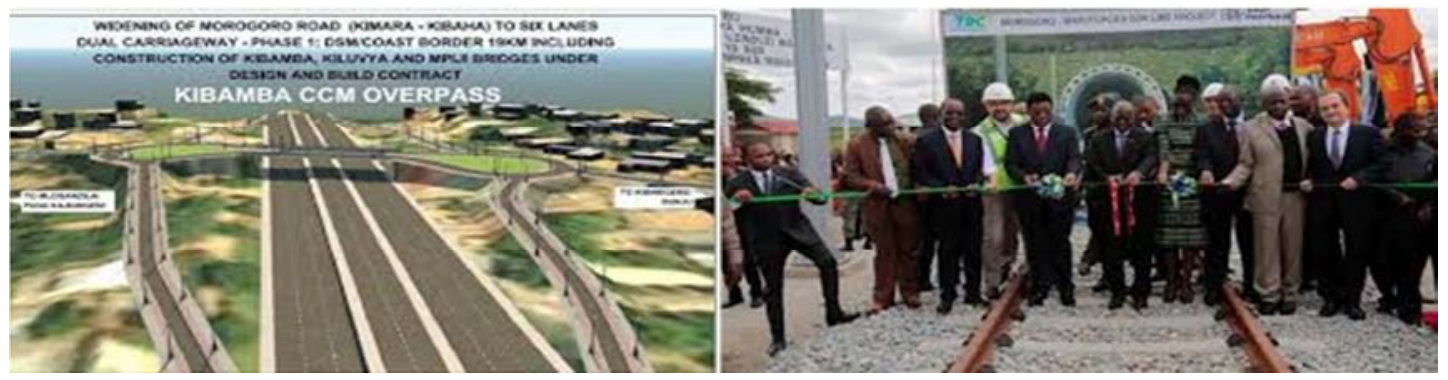




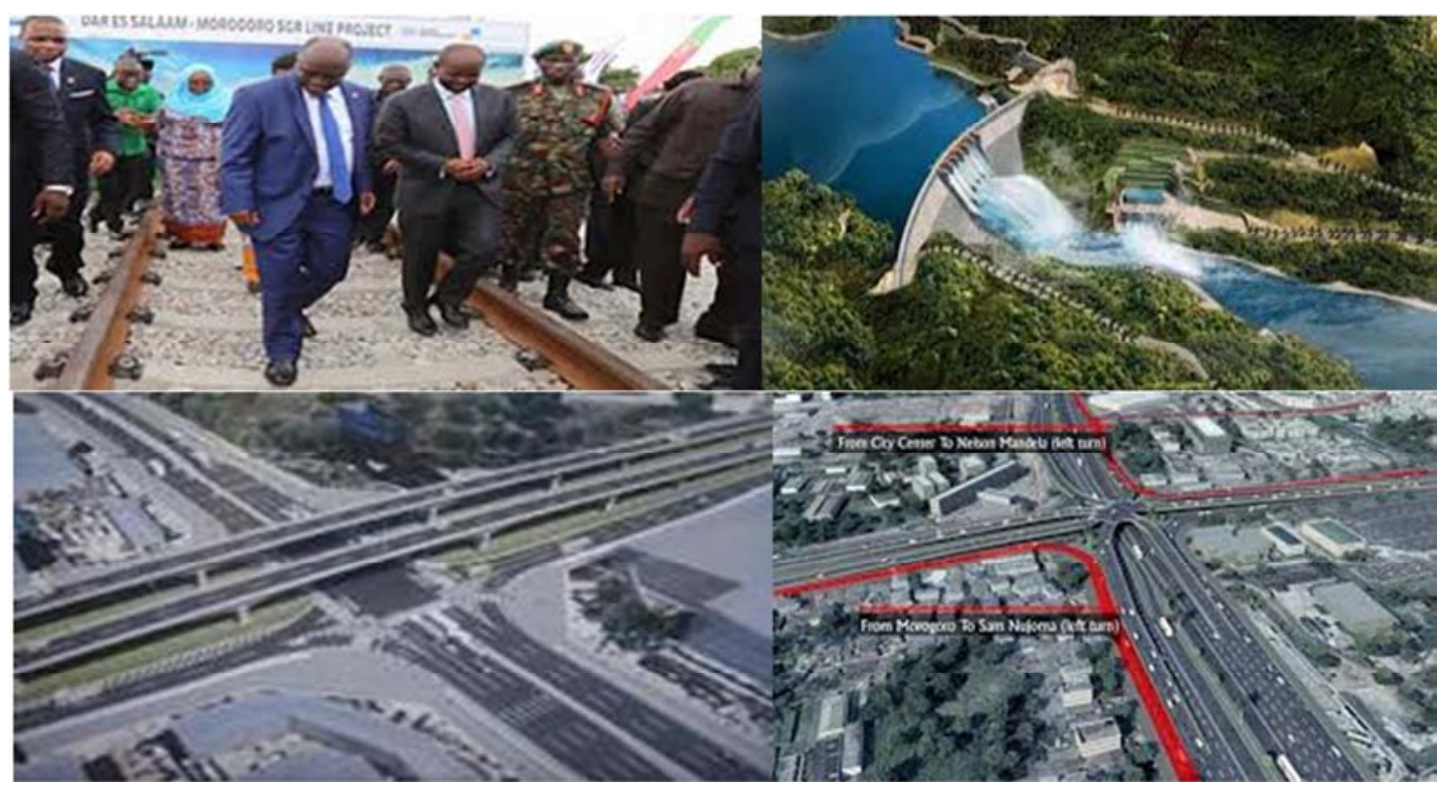

Figure 1. Various Strategic Projects under construction in Tanzania.

\section{Methods}

a. Case study Selection

To attain the opinion from the CI practitioner and stakeholders on the performance of Tanzania Construction Industry under the current government, only experienced (with more than five years) stakeholders were purposively selected from ten regions and interviewed. A total of 250 respondents were intended for the interview. Yamane's formula was adopted to compute the sample size. $n=\frac{N}{\left(1+N e^{2}\right.}$ $=153.8 \sim 154$

Where " $n$ " represents the corrected sample size (minimum number of respondents required), " $N$ " is the population size (Intended/assumed number of experienced stakeholders in CI), and "e" is the level of an acceptable sampling error. The assumed confidence level in this study was 95\% within acceptable sampling error of 0.05) [27]. Moreover, most stakeholders were found on different on-going construction sites for easy availability and accessibility that helped to save time and cost.

b. Questionnaire Administration

A questionnaire written in both English and Swahili language was divided into three parts: Part one provided an introduction to the study. Part two targeted to capture the respondent's demographic information, and part three comprised of performance variables and factors for outstanding performance within construction projects under the current government. However, the section also required to collect the opinion on essentials to attain sustainable performance and CI growth.

Using a judgemental and purposive random probability sampling technique, an intended 154 respondents as stakeholders were visited on different sites for the interview from July-October 2019. At the same time, another questionnaire was sent and hence administered through email and social media networks such as whattsup.
Respondents involved government employees with construction industry-related professionals, private contractors and consultants, employees from state-owned construction enterprises and consultant firms who work on force account projects under government umbrella such as public universities. A total of 119 filled questionnaire was collected and used for data analysis.

c. Data Analysis

Data collected were tested for validity \& reliability and analyzed using statistical packages for social science (SPSS 20). Descriptive statistics analysis involving frequencies, percentage, the mean and standard deviation were adopted to present the findings of the study.

\section{Findings and Discussion}

a. Respondents Information

The respondent's information has been summarized in table 1.

Table 1. Respondent's Demographic Information.

\begin{tabular}{llll}
\hline Item & Class & Frequency (Nos) & Percentage (\%) \\
\hline & $18-30$ & 19 & 16.00 \\
Age (Years) & $31-43$ & 38 & 31.93 \\
& $44-56$ & 45 & 37.82 \\
& Above 56 & 17 & 14.29 \\
Working & $5-10$ & 13 & 10.92 \\
Experience & $11-20$ & 47 & 39.50 \\
(Years) & $21-30$ & 33 & 27.73 \\
& Above 30 & 26 & 21.85 \\
Education & Diploma & 34 & 28.57 \\
Level & Degree & 46 & 38.66 \\
& Master & 23 & 19.33 \\
& PhD & 16 & 13.45 \\
\hline
\end{tabular}

b. Effects of Outstanding Performance

A list of consequences for outstanding performance was provided to respondents and required to rank them in order of their preference. The average mean score of the effects was 
computed and found to be 3.78. The findings (Table 2) indicated that effects (A-G) were noted as results of

outstanding performance to

Table 2. Outstanding Performance Outcomes.

\begin{tabular}{llll}
\hline Effects of Outstanding Performance & Remarks & Frequency \\
\hline Attainment Value for money & $\mathrm{A}$ & 4.06 & Percentage \\
Fight against malpractices (corruption) & $\mathrm{B}$ & 4.04 & 4.03 \\
Timely Project Completion & $\mathrm{C}$ & 4.01 & 1.34 \\
Society satisfaction with projects & $\mathrm{D}$ & 4.00 & 1.53 \\
Community participation/local fundi & $\mathrm{E}$ & 3.83 & 1.36 \\
Reduced of Construction cost & $\mathrm{F}$ & 3.79 & 3.76 \\
Abide to construction specification & $\mathrm{G}$ & 3.74 \\
Increased quality Social services & $\mathrm{I}$ & 3.58 \\
Suspending of ghost engineers & $\mathrm{H}$ & 3.31 \\
De-register incompetent contractors & $\mathrm{J}$ & $\mathrm{K}$ & 1.61 \\
Reasonable operational cost & $\mathrm{L}$ & 3.16 \\
Timely payment & & 1.37 \\
\hline
\end{tabular}

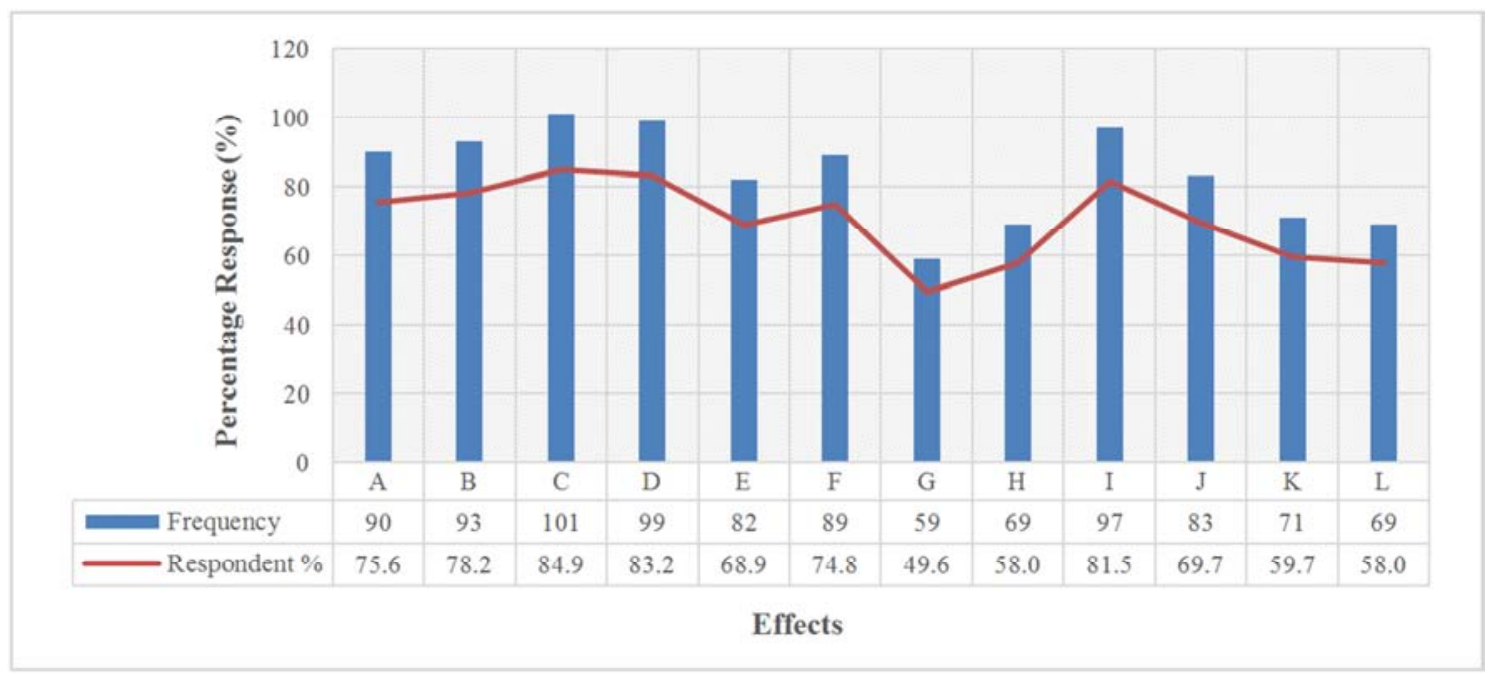

Figure 2. Effects of Outstanding Performance.

\section{c. Discussion}

In attempting to describe the effects of the outstanding performance in Tanzania CI, respondents pointed out various witnessed impacts as the result of the prevailing situation in the construction sector as explained hereunder:

i. Increased Construction Quality

In most completed construction projects, value for money in terms of quality, timely completion, and reduced construction and operational cost has been witnessed by most respondents. Some of the construction projects have been finished before the contractual time and within the acceptable quality while spending within the estimated budget. Before the fifth Tanzania government, almost all projects were extended in terms of time, cost with unsatisfactory quality. Thus, completed without value for money.

ii. Fighting Malpractices

Fighting against misconduct in Tanzania CI was noted as among the effects of accelerating outstanding performance. It extends from identifying ghost engineers who were expelled from being government employees. Further, fighting against malpractices in terms of corruption, constructing below standard and specification, changes of design in favor of contractors to get more profit, overestimation of construction cost etc. The government, through its supervisory agencies, has played a significant role in attaining the maximum and well utilization of public funds to achieve value for money.

iii. Society Satisfaction

Among the noticeable effects of outstanding performance is society satisfaction. Through their visual inspection and impression, many respondents were satisfied with the completed projects. The community participation during project execution through local skilled labor "fundi" [28] has resulted in their satisfaction. However, their presence as a construction team helped them to report any misconduct, they noticed that could harm the public fund and hence project quality

iv. Increased Quality Social Services

The increased quality of social services to the public was noted as among the effects of outstanding performance. Different public social services such as schools, colleges, health centers, folk development colleges, airports, roads, water dams, markets, and other public buildings have been renovated, attained the forgotten maintenance and newly constructed by the fifth phase government. An example is drawn to various old Secondary schools built in the 1970s which have never achieved maintenance thoroughly hence 
led to outdated infrastructures resulting in the underperformance of public schools [29]. The general maintenance program has proved increasingly quality social services that have created a conducive performance environment for most workers.

v. Timely payment

Many contractors, consultants, and suppliers who participated as respondents in this study were impressed with timely payment by the government as compared to past tenures. They have observed early payment of their dues ever seen before. In previous government phases, payments took much time as a result of losing their values during payment. The fifth government has been setting the fund before the commencement of the projects which have helped many goods and service providers in the projects to obtain their payment within reasonable and valuable time. This situation has also evidenced the outstanding performance of CI participants.

Conversely, the efforts undertaken to attain outstanding performance have been supported by Tanzania President. It was noted in one of his speeches when President Dr. John Magufuli directed the Ministry of Works, Transport and Communication to review laws about the construction industry to create a conducive performance environment for contractors to be able to participate in the execution of grand projects [30]. Further, he ordered the deregistration of incompetent contractors when said: "Underperforming contractors should not be allowed in this country."

\section{Conclusion}

Despite the effects of a strong government in realizing the outstanding performance of Tanzania Construction Industry. Respondents remarked some measures to be implemented by the same government for quick growth: The proposed measures Included the limited adoption of the force account method to some projects by the government to give construction opportunities to local firms for their growth. Also, preferences to local contractors on some projects were proposed as a means to upgrade the local firms. However, the policy on either a joint venture or partnership on public construction projects with overseas firms was emphasized as extremely important to facilitate knowledge, skills, experience and technology sharing between local and foreign firms.

\section{References}

[1] Abdullah, F. et al, " An Overview on the Growth and Development of the Malaysian Construction Industry. Workshop on Construction Contract Management," Malaysia, 2004.

[2] R. A. Khan, "Role of Construction Sector in Economic Growth Emprical Evidence from Pakistan Ekonomy", First International Conference on Construction In Developing Countries," Pakistan, 2008.
[3] P. M. Hillebrandt, Economic Theory and the Construction Industry, Third Edition ed., London: Macmillan Press LTD, 2000 .

[4] M. Jackman, "Investigating the relationship between residential construction and economic growth in a small developing country: The case of Barbados," International real estate review, 2010.

[5] J. Lopes, Construction in the economy and its role in socio-economic development. In G. Ofori (ed.). New Perspectives on Construction in Developing Countries, G. Ofori ed ed., Abingdon, UK: Spon Press, 2011.

[6] R. Navon, "Automated project performance control of construction projects," Automation in Construction, vol. 14, pp. PP. 467-476, 2005.

[7] Jorge, L. et al, "The sustainability of the construction industry in Sub-saharan Africa: some new evidence from recent data," Procedia Engineering, vol. 172, pp. 657-664, 2017.

[8] D. Amel, "The Contribution Of The Construction Industry To Economic Development In LIBYA. A PhD Thesis," John Moores University, Liverpool, 2013.

[9] URT, "Construction Industry Policy (CIP) Implementation," Ministry of works, Transport and Communication, Dar es Salaam, Tanzania, 2003.

[10] Muhegi, B. and Malongo, "Globalisation: A Challenge to Developing Countries." in Paper Presented at International Symposium on Globalisation and Construction," Bangkok, Thailand, 2004.

[11] MoW, "Ministry of Works [MoW]., (2003) Construction Industry Policy, Dar es Salaam, Tanzania," United Republic of Tanzania, Dar es Salaam, 2003.

[12] PPRA, "Public Procurement Regulatory Authority (PPRA)., (2008) Annual Performance Evaluation Report for the Financial year 2008/2009, Report, Dar es Salaam, Tanzania," PPRA, Dar es Salaam, 2008.

[13] Mhando, B. et al., "Perspectives of the Causes of Variations in Public Building Projects in Tanzania," International Journal of Construction Engineering and Management, vol. 6, no. 1, pp. $1-12,2017$.

[14] Karim K. and Marosszeky M, "Process monitoring for process re- engineering - using key performance indicators, International conference on construction process reengineering, CPR 99, Sedney UNSW 12-13 July, Building Research center," Sedney, 1999.

[15] G. Ofor, "Challenges of Construction Industries in Developing Countries: Lessons from Various Countries." in Proceedings of the 2nd International Conference of Construction in Developing Countries," Gaborone, Botswana, 2000.

[16] URT, "Govt pleased with use of force account in works," 2019. [Online].

Available: https://www.ppra.go.tz/index.php/news-archive/601-govt-plea sed-with-use-of-force-account-in-works. [Accessed 5 11 2019].

[17] D. Hancott, "The Relationship between Transformational Leadership and Organisational Performance in the Largest Public Companies in Canada. Doctoral Dissertation," Capella University, Minneapolis, 2005. 
[18] Reijonen, H. and Komppula, R, "Perception of Success and Its Effect on Small Firm Performance," Journal of Small Business and Enterprise Development, vol. 14, pp. 689-701, 2007.

[19] Samson M and Lema NM, "Development of construction contractors performance measurement framework, 1st International Conference of Creating a Sustainable," Dar Es salaam, 2002.

[20] F. Addo-Abedi, "Supporting the Local Consultants Industry for the Effective and Efficient Management of the National Road Network," 2006. [Online]. Available: Available at: http://www.acet.or.tz/gama/Supporting_local.htm. [Accessed 2710 2019].

[21] A. Digaga, "Establishment of Factors Towards Achieving Value for Money in Construction, the Case of Local Government Projects, Masters (Dissertation Mgt), University of Dar es salaam," University of Dar es salaam, Dar es salaam, 2010 .

[22] J. Ngowi, "Development of Stakeholder Management Framework For Application in Road Construction Projects in Tanzania, A Case Study of Roads Construction Projects under TANROADs, Masters of Engineering Management dissertation, University of Dar es Salaam," TANROAD, Dar es Salaam, 2014.

[23] MOF, "Ministry of Finance (MOF)., (2011) The Economic Survey, August, Dar es salaam, Tanzania," MOF, Dar es salaam, 2011.

[24] B. Muhegi, "A Perspective of Contractor Regulation, Development and Performance over Fifty Years and Challenges of Empowering Contractors, Proceedings of the
Annual Consultative Meeting, 50 Years of Independence: Empowering Contractors to Meet the Challenges Ahead. DSM," Da Es Salaam, 2011.

[25] J. Shengeza, "Procedure on Effective Application of Force Account as a Method of Procurement for Renovation and Remodeling of Government Building Projects," Journal of Civil, Construction and Environmental Engineering, vol. 2, no. 6, pp. 153-158., 2018.

[26] URT, "On-Going Construction Project," 2019. [Online]. Available: https://en.wikipedia.org/wiki/Ministry_of_Works,_Transport_ and_Communications. [Accessed 811 2019].

[27] Singh, A. and Masuku, M., "Sampling techniques \& determination of sample size in applied statistics research: an overview," International Journal of Economics, Commerce and Management, vol. 2, no. 11, p., 2014.

[28] R. Tekka, "Economic Empowerment of Local Skilled Labour Through Force Account in Building Renovation," Journal of Civil, Construction and Environmental Engineering, vol. 2, no. 6, pp. 159-154, 2017.

[29] D. News, "88 Old Secondary Schools to be Renovated to Improve Education," 2017. [Online]. Available: https://www.dailynews.co.tz/news/88-old-secondary-schools-t o-be-renovated-to-improve-education.aspx\#. [Accessed 1510 2019].

[30] URT, "Tanzanian president orders deregistration of incompetent contractors," 2019. [Online]. Available: http://www.xinhuanet.com/english/africa/2019-09/04/c_13836 5121.htm. [Accessed 1810 2019]. 